\title{
Evaluation of Cocoa Bean Hulls as a Fat Replacer On Functional Cake Production
}

\section{Elif Öztürk, Gülden Ova*}

Department of Food Engineering, Faculty of Engineering, Ege University, 35100 Bornova/Izmir, Turkey

\section{A R T I C LE INFO}

\section{Research Article}

Received 28 March 2018

Accepted 25 June 2018

Keywords:

Cocoa bean hulls

Fat substituted cakes

Total antioxidant activity

Total phenolic compounds

Fiber

\footnotetext{
*Corresponding Author:

E-mail: gulden.ova@ege.edu.tr

DOI: https://doi.org/10.24925/turjaf.v6i8.1043-1050.1934
}

A B S T R A C T
substituted cakes.
The effects of raw and leached cocoa bean hulls were investigated as a fat replacer in pound cakes. This substitution was applied for raw $(\mathrm{RCBH})$ and leached $(\mathrm{LCBH})$ grinded cacao bean hulls/oil in the ratios of 30/70 (30\%), 40/60 (40\%) and 50/50 (50\%). Chemical, physical and sensorial properties of raw and leached cocoa bean hulls were studied as well as fat substituted cakes. Ash, protein, total phenolic compounds and total antioxidant activity decreased with leaching process. Crude fiber content increased in fat substituted cakes compared to control cake. RCBH cakes showed higher bioactive components than LCBH cakes because of raw cocoa bean hulls were higher phenolic compounds and total antioxidant activities than leached cocoa bean hulls. The results showed that $50 \%$ of vegetable oil replacement with raw cocoa bean hull in cake formulation significantly improved chemical, physical and sensory properties of fat

\section{Introduction}

Globe cocoa (Theobroma cacao L.) is a perennial plant whose every fruits include almost 30-40 cocoa beans (Kongor et al., 2016). Côte d'Ivoire, Ghana, Indonesia, Nigeria, Ecuador, Cameroon, and Brazil produce $90 \%$ of the world's total cocoa bean production. It is estimated that 4230 thousand tons of cocoa bean for the 2014/2015 was harvested (ICO, 2016). Cocoa bean hulls are obtained from as an industrial by-product during cocoa production which is removed together with the germ before or after roasting (Beckett, 2008, 2009). Cocoa bean hull is mostly used as a fuel for boilers as well as animal feed, fertilizer preparation, packaging material, theobromine and caffeine extraction (Prasad et al., 2004; Arlorio et al., 2005). It is stated that cocoa bean hull represents $12 \%-15 \%$ of the cocoa bean (Kopp et al., 2011). According to ICO (2016), almost 700 thousand tons of cocoa bean hulls were generated per year during cocoa bean production which is important amounts. It is stated that cocoa bean hulls include in nutritional value (Lecumberri et al., 2007; Martinez et al., 2012). The ash, protein, fat, dietary fiber, polyphenols of cocoa bean hulls evaluated by Lecumberri et al. (2007) showed $11.42 \%$, $16.7 \%, 6.6 \%, 60.5 \%, 5.8 \%$, respectively. The moisture contents of cocoa bean hulls were determined by MartínCabrejas et al. (1994) was 4.7\%, by Arlorio et al. (2001) was $10.1 \%$ and by Martinez et al. (2012) was $7.7 \%$. In addition, phenolic compounds and dietary fiber contents were high amounts in cocoa bean hulls so that cocoa bean hulls could be applied as dietary fiber, antioxidant additive and colorant/flavoring agent sources (Okiyama et al., 2017). Furthermore, Lecumberri et al. (2007) suggested that cocoa bean hull which was produced after sterilization and grinding to $75-\mu \mathrm{m}$ pieces process as fiber rich product might be used low-calorie, high-fiber foods such as chocolate cakes, chocolate cookies, dietetic chocolate supplements etc. In an another study, cocoa bean hulls were obtained by patented enzymatic process as a soluble cocoa fiber which was applied for wheat bread quality determination by Collar et al. (2009) and for chocolate muffins as a fat replacer by Martínez-Cervera et al. (2011). Martinez et al. (2012) evaluated antioxidant properties of cocoa bean hulls which were treated with warm water $\left(30^{\circ} \mathrm{C}\right)$ and dried $\left(60^{\circ} \mathrm{C}\right)$ fiber concentrates and stated that this fiber-rich cocoa by-product could be used as intermediate functional foods ingredients for developing functional foods. Arlorio et al. (2005) extracted cocoa bean hulls by supercritical $\mathrm{CO}_{2}$ method, obtained extracts of phenolic compounds and pigments from cocoa bean hulls in order to use as a functional colorant ingredient or antioxidant rich component. 
The present study aims to determine raw and leached cocoa bean hulls based on nutritional and bioactive compounds and evaluate those compounds of cocoa bean hulls after leaching process. Second part of this paper was dedicated to studying the addition of $30 \%-40 \%-50 \%$ raw and leached cocoa bean hulls as a fat replacer for pound cake production and to determine the effect of chemical, physical and sensorial properties of cake and the final quality of the resulting cake. The overall quality parameters between raw and leached cocoa bean hull substituted cakes have been compared. Functional properties of cakes have been determined in order to evaluate the advantages of cake with raw or leached cocoa bean hull replacement. The specificity of our work is to determine and compare the effects of adding cocoa bean hulls to cake formulations, raw and leached by hot water, to cake quality. In previous studies, hull powders of oilseeds were subjected to alkali treatment to produce hull powders with high fiber content (Garcia-Serna et al., 2014; Yang et al., 2014). Another object of treating the cocoa bean hulls with water as an alkali solvent is to treat the cocoa bean hulls with increased fiber content to determine the advantages and disadvantages of the cocoa bean hull with respect to the produce to be produced with the raw cocoa bean hulls in the production of high fiber cakes.

\section{Materials and Methods}

\section{Cocoa Bean Hulls}

Cocoa bean hulls were obtained by Ülker Chocolate Industry Incorporated Company. Raw cocoa bean hulls $(\mathrm{RCBH})$ were ground into a fine powder using a hammer mill (Brook Crompton Series, 2000) with 60 mesh steel sieve. Some part of RCBH fine powder was leached by hot water extraction using the method described by Garcia-Serna et al. (2014). $3.3 \mathrm{~g}$ of RCBH fine powder was treated with $100 \mathrm{ml}$ boiling water for $10 \mathrm{~min}$. The solid residue from the extraction process was recovered by filtration using Whatmann no. 4 paper and dried at $60 \pm 2{ }^{\circ} \mathrm{C}$ in air oven for $24 \mathrm{~h}$. The leached cocoa bean hull $(\mathrm{LCBH})$ fine powder was obtained.

\section{Preparation of Cakes}

Cake formulation contained the following ingredients: $26.14 \%$ wheat flour; $26.14 \%$ sugar; $12.03 \%$ sunflower oil; $21.18 \%$ egg; $0.39 \%$ salt; 13.07 whole milk; $1.05 \%$ baking powder. Before the current experiment, a ranking test was conducted between 10\%-20\%-30\%-40\%-50\%-60\% in sensory analysis to determine the available range of cocoa bean hulls that could be incorporate in the fat substituted cakes in terms of color, texture (hand and mouth), taste and overall acceptance properties. It was found that $30 \%$ 40\%-50\% RCBH and LCBH powders were appropriate levels by replacing equivalent amount of sunflower oil of the cake mixture. Totally 7 cakes were baked for each repetition. Control cake and three levels of fat substituted cakes with $\mathrm{RCBH}$ and $\mathrm{LCBH}$ powders were obtained, respectively. The batter was massed $(600 \mathrm{~g})$ into Teflon cake mold $(31 \times 12 \times 7 \mathrm{~cm})$ and baked in a preheated oven (Suf4000 meb, Arçelik, Turkey) at $170^{\circ} \mathrm{C}$ for $55 \mathrm{~min}$. Cakes for chemical analysis were ground by using a coffee grinder and their extracts were stored at $-18^{\circ} \mathrm{C}$ in airtight vials.

\section{Chemical Analysis on Cocoa Bean Hulls and Cakes}

Proximate composition: $\mathrm{RCBH}$ and $\mathrm{LCBH}$ powders and their cake samples were subjected to proximate analysis using methods of the AOAC (2007): fat (Method 963.15), protein (Method 968.06), ash (Method 942.05), and crude fiber (Method 962.09). Moisture content of $\mathrm{RCBH}$ and $\mathrm{LCBH}$ powders were determined by Method 925.10 (AOAC, 2007). Moisture of cake samples were also measured based on Method 44-40 (AACC, 2000a).

Preparation of extracts of cocoa bean hulls and cakes for phenolic and antioxidant assay: $40 \mathrm{ml}$ of methanol: water (v/v, 80:20) was added to $2 \mathrm{~g}$ of RCBH and LCBH powder and defatted cakes chloroform: petroleum ether (v/v, 50:50) was applied for obtaining defatted cake samples. The mixtures were then subjected to shake in Wiseshake for $142 \mathrm{rpm}$ for $2 \mathrm{~h}$. The crude extract was centrifuge (Mistral 1000) at $4500 \mathrm{rpm}$ for $15 \mathrm{~min}$. The supernatant was transferred to $50 \mathrm{ml}$ volumetric flask. (Skerget et al., 2005; Balestra et al., 2011). Samples of each treatment were extracted for determining total phenolic content (TPC) and total antioxidant activity (TAC) immediately.

Determination of total phenolic content (TPC): TPC in extracts were determined based on Folin-Ciocalteu assay as described by Heimler et al. (2005). The samples were measured at $765 \mathrm{~nm}$ at UV-spectrophotometer (Varian Cary 60 Scan). Results were expressed as mg of Gallic acid equivalent (GAE) per $100 \mathrm{~g}$ dry weight (mg GAE/100g dw).

Determination of total antioxidant activity (TAC): The DPPH assay was performed according to Saija et al. (1998) and Rapisarda et al. (1999) with some modifications. The reaction reagent (DPPH solution) was made immediately before the assay. The samples were measured at $517 \mathrm{~nm}$ at UV-spectrophotometer (Varian Cary 60 Scan). DPPH values were expressed as $\mu \mathrm{mol}$ Trolox equivalents (TE) per g dry weight.

\section{Physical Analysis on Cakes}

Specific volume: The volume of each cake was measured after baking and 1-hour cooling by Method 1005 (AACC, 2000b). The specific volume was calculated by dividing loaf volume by loaf weight $\left(\mathrm{cm}^{3} / \mathrm{g}\right)$.

Baking loss: Baking loss of cakes was also calculated by difference before and after baking and 1-hour cooling of cakes divided by cake mold which was before baking and results were expressed as percentage (MartínezCervera et al., 2011).

Texture and color determination: Texture analyses were conducted on a TA.TX.Plus Texture Analyzer (Stable Microsystems, Godalming, UK). Cake loaves were cut into $25 \mathrm{~mm}$ thick slices from the center for a standard texture profile analysis (TPA) test using a 36 $\mathrm{mm}$ dia cylindrical probe at a speed of $1 \mathrm{~mm} / \mathrm{s}$ with a $5-\mathrm{s}$ waiting time between two cycles. A double compression test was carried out to a height of $1.25 \mathrm{~cm}$ with $40 \%$ compression. Hardness $(\mathrm{N})$, cohesiveness, springiness and chewiness $(\mathrm{N})$ of cakes were determined by the modified method of AACC (2000c).

Color was determined on crust and crumb using Minolta Colorimeter (CR-400, Konica Minolta Sensing, Inc., and Osaka, Japan). 
The instrument was calibrated before analysis with white and black standard tiles. L* (lightness, black=0, white $=100), a^{*}$ (redness $>0$, greenness $\left.<0\right), b^{*}($ yellowness, $b^{*}>0$, blue $b^{*}<0$ ) were quantified on each sample.

Crust and crumb color were determined on 5 preselected locations on the crust and crumb of each loaf.

\section{Sensory Evaluation}

Approval to conduct a sensory panel evaluation was received from food engineering department of Ege University. Six trained panelists participated from the master student in Dept. of Food Engineering. Training session included appearance, texture and flavor characteristics of fat- substituted cakes using a 0-7 point line scale. Related definitions about crumb brownness, cell uniformity, adhesiveness, hardness (mouth \& hand), oiliness, moistness, fibrousness, sweetness were shown on the Table 1. Panelists evaluated 6 samples of each item with $30 \%-40 \%-50 \% \mathrm{RCBH}$ and $\mathrm{LCBH}$ powder for fat substituted cakes. Cake samples with a thickness of 25 $\mathrm{mm}$ were randomly selected and then coded with 3-digit numbers and presented to the panelists in random order on white plastic plates (Altuğ and Elmac1, 2005).

\section{Statistical Analysis}

Means and standard deviations of data were calculated with SPSS (Version 20.0 SPSS Inc., Chicago, IL) statistical software. SPSS was used to perform independent t-test for raw and leached cocoa bean hull results and one-way analysis of variance (ANOVA) and Duncan multiple comparison test at a $95 \%$ confidence level $(\mathrm{p}<0.05)$ was further used to identify differences among cake samples. Profile compound analysis (PCA) and cluster analysis also applied for descriptive sensory analysis. In this study, three parallels were used for $\mathrm{RCBH}$ and $\mathrm{LCBH}$ powders, two parallels and two repetitions were applied for cake samples.

Table1 Descriptive terms and definitions used in sensory analysis of cakes by trained panelists

\begin{tabular}{l|l}
\hline \multicolumn{1}{c|}{ Terms } & \multicolumn{1}{c}{ Definitions } \\
\hline Appearance & \\
$\begin{array}{l}\text { Crumb browness } \\
\text { Cell uniformity }\end{array}$ & Typical cocoa colour in cake crumb \\
Texture (hand) & Amount and size of gas cells, homogeneity of air bubbles \\
Hardness (hand) & Speed of crumb shape recovery when pressure applied by a finger and then is removed \\
Adhesiveness & Easily roll a piece of cake crumb \\
Texture (mouth) & Resistance to chewing and difficulty in swallowing \\
Hardness (mouth) & Oiliness in the mouth \\
Oiliness & Cake moisture in the mouth \\
Moistness & Residual in the mouth \\
Fibrousness & Typical cocoa taste intensity \\
Flavour & Bitterness from cocoa \\
Cocoa taste & Fruity woody odor \\
Bitterness & Sweetness intensity \\
Woody odor & Sweetness
\end{tabular}

\section{Results and Discussion}

\section{Chemical Composition}

Chemical composition of cocoa bean hulls: Chemical properties of raw and leached cocoa bean hulls are summarized in Table 2. The moisture contents of RCBH and $\mathrm{LCBH}$ are $6.36 \%$ and $9.57 \%$, respectively. Ash, protein, total phenolic contents and total antioxidant activity of raw cocoa bean hulls decreased with leaching process (Table 2). No significant differences $(p>0.05)$ in the fat and crude fiber content were found between raw and leached cocoa bean hulls. Moisture content in cocoa bean hulls seen in Table 2 is similar to the moisture of cocoa bean hulls which are $10.1 \%$ and $7.7 \%$ based on dry matter, respectively reported by Arlorio et al. (2001) and Martínez et al. (2012). The ash, protein content of raw cocoa bean hulls in line with the values reported by (Lecumberri et al., 2007). Crude fiber content of cocoa bean hulls evaluated by Altuğ. (1987) showed approximately $19.70 \%$ which showed similar results in cocoa bean hulls in Table 2 .

Bruna et al. (2009), evaluating the cocoa bean hulls harvested in Madagascar, Gana, Venezuela, Ecuador,
Trinidad regions, noted that of the total phenolic contents determined between 256-406 $\mathrm{mg}$ GAE/100g in concordance with TAC content of raw cocoa bean hulls in Table 2. Martinez et al. (2012) reported that TAC contents of leached cocoa bean hulls from Taura and Cone origin between 144.83 - $154.43 \mathrm{mg}$ GAE/100 g, respectively. TAC values of $\mathrm{LCBH}$ powder in Table 2 showed less value than TAC values of leached cocoa bean hulls of Matinez et al. (2012) depend on temperature of hot water, drying temperature and time during leaching process.

Total antioxidant activity of RCBH and $\mathrm{LCBH}$ values were determined as 17.27 and $2.38 \mu \mathrm{mol}$ Troloks/g dm. Martinez et al. (2012) evaluated TAC values of leached cocoa bean hulls between 3.81-4.05 $\mu \mathrm{M}$ Trolox/g dm. In an another study for determination of TAC values of cocoa bean hulls was obtained $7.73 \mu \mathrm{mol}$ Troloks $/ \mathrm{g} \mathrm{km}$. Methods of antioxidant activity, origin of cocoa bean hulls showed differences about total antioxidant activities of cocoa bean hulls values (Martinez et al., 2012; Bruna et al., 2009). 
Table 2 Chemical and bioactive properties of cocoa bean hulls and cakes

\begin{tabular}{|c|c|c|c|c|c|c|c|}
\hline & $\begin{array}{c}\mathrm{M} \\
(\%)\end{array}$ & $\begin{array}{c}\mathrm{A} \\
(\mathrm{g} / 100 \mathrm{~g} \mathrm{dm})\end{array}$ & $\begin{array}{c}\mathrm{P} \\
(\mathrm{g} / 100 \mathrm{~g} \mathrm{dm})\end{array}$ & $\begin{array}{c}F \\
(\mathrm{~g} / 100 \mathrm{~g} \mathrm{dm})\end{array}$ & $\begin{array}{c}\mathrm{CF} \\
(\mathrm{g} / 100 \mathrm{~g} \mathrm{dm})\end{array}$ & 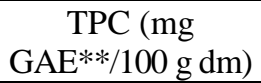 & $\begin{array}{c}\text { TAA }(\mu \mathrm{mol} \\
\text { Troloks } / g \mathrm{dm})\end{array}$ \\
\hline \multicolumn{8}{|c|}{ Cocoa bean hulls } \\
\hline$\overline{\mathrm{RCBH}}$ & $6.36 \pm 0.12^{\mathrm{a}^{*}}$ & $11.42 \pm 1.46^{\mathrm{a}}$ & $16.05 \pm 0.09^{\mathrm{a}}$ & $4.37 \pm 0.38^{\mathrm{a}}$ & $17.66 \pm 0.27^{\mathrm{a}}$ & $370.97 \pm 0.03^{\mathrm{a}}$ & $17.27 \pm 0.46^{\mathrm{a}}$ \\
\hline $\mathrm{LCBH}$ & $9.57 \pm 1.62^{\mathrm{b}}$ & $5.22 \pm 0.11^{\mathrm{b}}$ & $14.82 \pm 0.27^{\mathrm{b}}$ & $4.70 \pm 0.48^{\mathrm{a}}$ & $18.48 \pm 0.13^{a}$ & $39.25 \pm 2.26^{\mathrm{b}}$ & $2.38 \pm 0.17^{\mathrm{b}}$ \\
\hline \multicolumn{8}{|c|}{ Cake Samples } \\
\hline Control & $29.26 \pm 0.35^{b^{*}}$ & $2.29 \pm 0.16^{\mathrm{a}}$ & $8.14 \pm 0.17^{\mathrm{a}, \mathrm{b}}$ & $19.06 \pm 1.52^{\mathrm{c}}$ & $0.55 \pm 0.44^{\mathrm{a}}$ & $17.34 \pm 0.82^{\mathrm{a}^{*}}$ & $0.70 \pm 0.02^{\mathrm{a}}$ \\
\hline $30 \mathrm{RCBH}$ & $28.25 \pm 1.20^{\mathrm{a}, \mathrm{b}}$ & $2.64 \pm 0.20^{\mathrm{b}, \mathrm{c}}$ & $7.84 \pm 0.69^{\mathrm{a}}$ & $11.26 \pm 2.61^{\mathrm{a}, \mathrm{b}}$ & $1.63 \pm 0.08^{b}$ & $30.99 \pm 0.03^{b}$ & $3.85 \pm 0.62^{\mathrm{b}}$ \\
\hline 40RCBH & $28.87 \pm 0.19^{\mathrm{a}, \mathrm{b}}$ & $2.74 \pm 0.26^{\mathrm{c}}$ & $8.32 \pm 0.30^{\mathrm{a}, \mathrm{b}, \mathrm{c}}$ & $11.68 \pm 1.02^{\mathrm{a}, \mathrm{b}}$ & $1.59 \pm 0.14^{\mathrm{b}}$ & $82.60 \pm 8.50^{\mathrm{c}}$ & $4.78 \pm 1.86^{\mathrm{b}, \mathrm{c}}$ \\
\hline $50 \mathrm{RCBH}$ & $27.92 \pm 0.57^{\mathrm{a}, \mathrm{b}}$ & $2.77 \pm 0.13^{c}$ & $8.32 \pm 0.28^{\mathrm{a}, \mathrm{b}, \mathrm{c}}$ & $9.99 \pm 0.91^{\mathrm{a}, \mathrm{b}}$ & $2.18 \pm 0.02^{b}$ & $95.15 \pm 9.27^{\mathrm{d}}$ & $6.16 \pm 0.86^{\mathrm{c}}$ \\
\hline $30 \mathrm{LCBH}$ & $28.23 \pm 0.80^{\mathrm{a}, \mathrm{b}}$ & $2.40 \pm 0.29^{\mathrm{a}, \mathrm{b}}$ & $8.26 \pm 0.18^{\mathrm{a}, \mathrm{b}}$ & $12.78 \pm 2.57^{\mathrm{b}}$ & $1.73 \pm 0.22^{b}$ & $20.52 \pm 8.59^{a}$ & $1.08 \pm 0.98^{\mathrm{a}}$ \\
\hline $40 \mathrm{LCBH}$ & $27.90 \pm 0.53^{\mathrm{a}, \mathrm{b}}$ & $2.53 \pm 0.18^{\mathrm{a}, \mathrm{b}, \mathrm{c}}$ & $8.46 \pm 0.12^{\mathrm{b}, \mathrm{c}}$ & $10.10 \pm 0.87^{\mathrm{a}, \mathrm{b}}$ & $1.77 \pm 0.43^{\mathrm{b}}$ & $33.61 \pm 1.38^{\mathrm{b}}$ & $1.81 \pm 0.45^{\mathrm{a}}$ \\
\hline $50 \mathrm{LCBH}$ & $28.16 \pm 1.34^{\mathrm{a}, \mathrm{b}}$ & $2.80 \pm 0.13^{\mathrm{c}}$ & $8.87 \pm 0.38^{c}$ & $9.08 \pm 2.29^{\mathrm{a}}$ & $1.93 \pm 0.11^{\mathrm{b}}$ & $35.24 \pm 2.17^{\mathrm{b}}$ & $1.87 \pm 1.08^{\mathrm{a}}$ \\
\hline
\end{tabular}

M: Moisture, A: Ash, P: Protein, F: Fat, CF: Crude fiber, TPC: Total phenolic compounds, TAA: Total antioxidant activity, Means \pm standard deviation followed by different letters within a column for each cultivar are significantly different at $\mathrm{P}<0.05, * \mathrm{dm}=\mathrm{dry}$ matter, $* * \mathrm{GAE}=\mathrm{gallic}$ acid equivalent

Table 3 Physical and texture properties of cakes

\begin{tabular}{l|cccccc}
\hline & \multicolumn{2}{|c}{ Physical characteristics } & \multicolumn{3}{c}{ Textural characteristics } \\
\cline { 2 - 7 } & Specific volume $\left(\mathrm{cm}^{3} / \mathrm{g}\right)$ & Baking loss $(\%)$ & Hardness $(\mathrm{N})$ & Springiness & Cohesiveness & Chewiness(N) \\
\hline Control & $2.16 \pm 0.20^{\mathrm{a}}$ & $7.29 \pm 0.34^{\mathrm{b}}$ & $11.5 \pm 0.86^{\mathrm{a}}{ }^{\mathrm{a}}$ & $0.94 \pm 0.02^{\mathrm{a}}$ & $0.77 \pm 0.01^{\mathrm{c}}$ & $8.23 \pm 0.55^{\mathrm{a}, \mathrm{b}}$ \\
$30 \mathrm{RCBH}$ & $2.14 \pm 0.04^{\mathrm{a}}$ & $5.47 \pm 0.05^{\mathrm{a}}$ & $12.6 \pm 1.35^{\mathrm{a}, \mathrm{b}}$ & $0.89 \pm 0.03^{\mathrm{a}}$ & $0.66 \pm 0.05^{\mathrm{a}, \mathrm{b}}$ & $7.47 \pm 1.39^{\mathrm{a}}$ \\
$40 \mathrm{RCBH}$ & $2.10 \pm 0.12^{\mathrm{a}}$ & $5.70 \pm 0.24^{\mathrm{a}}$ & $15.6 \pm 0.46^{\mathrm{b}}$ & $0.91 \pm 0.03^{\mathrm{a}}$ & $0.62 \pm 0.05^{\mathrm{a}}$ & $8.75 \pm 1.20^{\mathrm{a}, \mathrm{b}}$ \\
$50 \mathrm{RCBH}$ & $2.00 \pm 0.15^{\mathrm{a}}$ & $7.11 \pm 0.21^{\mathrm{b}}$ & $21.9 \pm 3.18^{\mathrm{c}}$ & $0.88 \pm 0.06^{\mathrm{a}}$ & $0.61 \pm 0.07^{\mathrm{a}}$ & $11.77 \pm 1.69^{\mathrm{b}}$ \\
$30 \mathrm{LCBH}$ & $2.16 \pm 0.03^{\mathrm{a}}$ & $6.78 \pm 0.42^{\mathrm{b}}$ & $15.1 \pm 2.86^{\mathrm{a}, \mathrm{b}}$ & $0.90 \pm 0.06^{\mathrm{a}}$ & $0.72 \pm 0.07^{\mathrm{b}, \mathrm{c}}$ & $9.97 \pm 3.30^{\mathrm{a}, \mathrm{b}}$ \\
40LCBH & $2.27 \pm 0.15^{\mathrm{a}}$ & $6.80 \pm 0.46^{\mathrm{b}}$ & $16.1 \pm 3.53^{\mathrm{b}}$ & $0.92 \pm 0.06^{\mathrm{a}}$ & $0.70 \pm 0.04^{\mathrm{a}, \mathrm{b}, \mathrm{c}}$ & $10.45 \pm 2.95^{\mathrm{a}, \mathrm{b}}$ \\
$50 \mathrm{LCBH}$ & $2.18 \pm 0.18^{\mathrm{a}}$ & $7.35 \pm 0.25^{\mathrm{b}}$ & $20.0 \pm 3.28^{\mathrm{c}}$ & $0.92 \pm 0.02^{\mathrm{a}}$ & $0.62 \pm 0.04^{\mathrm{a}}$ & $11.45 \pm 2.63^{\mathrm{b}}$ \\
\hline
\end{tabular}

Means \pm standard deviation followed by different letters within a column for each cultivar are significantly different at $\mathrm{P}<0.05$

Chemical composition of cake samples: The moisture content of cakes was reduced by adding cocoa bean hulls to the formulation compared to control cake. No significant difference $(\mathrm{P}>0.05)$ in the moisture content were found between cakes with cocoa bean hulls. Protein content of 50LCBH cake was found the highest values, $30 \mathrm{RCBH}$ was the lowest values.

Fernandes and Salas-Mellado (2017) prepared chocolate cakes with chia mucilage dried at $50^{\circ} \mathrm{C}$ as a fat replacer with different levels of substitution: 25\%-50\%$75 \%-100 \%$. Moisture of fat substituted cakes were determined as $35.73 \%-37.22 \%-36.50 \%-38.52 \%$, protein contents of cakes were also determined as $8.75 \%-7.87 \%$ $8.46 \%-9.13 \%$, respectively. It was reported that the ratio of chia mucilage in cake samples increased, higher moisture and higher protein content were obtained. In literature it was presented that fiber rich hulls or skin of seeds such as cocoa bean hull or grape skin which were woody or membranous structure effected water holding capacity. For this reason, the difference in the water holding capacities of raw agro-materials used as the fiber source causes the moisture content of the produced cakes to diversity (Chaplin, 2003).

This study showed that fat content of cakes with RCBH decreased $47.59 \%$; cakes with LCBH decreased $52.36 \%$. Fernandes and Salas-Mellado (2017) applied for chia mucilage to cakes as a fat replacer and decreased $77.5 \%$ of fat content with $100 \%$ of fat replaced with dried chia mucilage at $50^{\circ} \mathrm{C}$. However complete removal of fat showed lower scores for texture, lightness, color, body and smoothness of the product.

As cocoa bean hull addition increased in cake samples, ash and crude fiber contents of cakes increased.
Crude fiber content of cakes showed significant differences compared to control cake $(\mathrm{P}<0.05)$ (Table 2).

Both TPC and TAC values of LCBH cakes were lower than $\mathrm{RCBH}$ cakes which includes in the same ratio of cocoa bean hulls. Cocoa bean hull replacement with oil in cake formulation increased TAC and TPC content of cakes.

\section{Physical and Texture Properties of Cakes}

Regarding specific volume, Table 3 showed no significant decrease of this parameter as consequence of cocoa bean hull addition ( $\mathrm{P}>0.05)$. The substitution of 30 40 and $50 \%$ of fat in cakes with cocoa bean hulls showed no affect the cake volume.

Baking loss of raw cocoa bean hull replaced cakes was found lower than control cake while LCBH and control cakes showed no significant difference $(\mathrm{P}>0.05)$. It was found that the baking loss of LCBH cakes was higher than with RCBH cakes. With the use of cocoa bean hull that is essentially contained in fibers, the water retention was high. The free water was reduced, not allowing its evaporation during the baking step of cakes. Thus, baking loss found less in fat substituted cakes. Baking loss decreased with using chia mucilage as a fat replacer in common with Fernandes and Salas Mellado (2017)

Textural properties of the seven cake samples are reported in Table 3. Hardness and chewiness of cakes increased due to the increase in the amount of cocoa bean hulls in cake formulations while cohesiveness decreased. No significant difference was found for springiness values between all cake samples $(\mathrm{P}>0.05)$. Hardness, springiness, cohesiveness and chewiness values of LCBH 
cakes were higher than RCBH cakes between the same amounts of cocoa bean hull added cake formulations.

Recently, Fernandes and Salas-Mellado. (2017) studied firmness of chia mucilage substitution of fat with different ratios of cakes. The authors found that firmness of cakes increased as chia mucilage substitution increased.

\section{Crust and Crumb Color of Cakes}

Color analysis of the crust indicated that $\mathrm{L}^{*}, \mathrm{a}^{*}, \mathrm{~b}^{*}$ values of RCBH cakes showed higher amounts than LCBH cakes. No significant difference was found in $\mathrm{L}^{*}$ value of cake crumb between the same content of cocoa bean hull added RCBH and LCBH cakes $(\mathrm{P}>0.05)$ (Table 4). As ratio of cocoa bean hull content increased, $b^{*}, a^{*}$ values of cake crumb decreased. In addition, $\mathrm{a}^{*}$ and $\mathrm{b}^{*}$ values of RCBH cake crumb was also higher than LCBH cake crumb. Furthermore, differences between color of $\mathrm{RCBH}$ and LCBH cakes is shown in Figure 1. According to the study of Fernandes and Salas-Mellado. (2017), chia mucilage replaced cakes promoted increased brightness of fat substituted cakes. $\mathrm{L}^{*}$ values of crumb and crust of cakes also increased with replacement of fat.

Descriptive Sensory Analysis

0-7 point line with twelve descriptive properties of fat substituted cakes is indicated as Figure 2. As the ratio of cocoa bean hull increased in cake formulation, crumb brownness increased. Crumb brownness of LCBH cakes were lower values than RCBH cakes. Clustering analysis and principal component analysis (PCA) were applied for determination the relation among fat substituted cakes in Figure $3 \mathrm{~A}$ and $3 \mathrm{~B}$, respectively. According to cluster analysis, it was indicated that three basic groups of fat substituted cakes in Figure 3A. First, second and third groups were observed as 50RCBH-50LCBH, 40RCBH$40 \mathrm{LCBH}$, and 30RCBH-30LCBH, respectively. 5 basic components, namely F1, F2, F3, F4 and F5, which are $67.83 \%, 20.99 \%, 4.99 \%, 4.29 \%, 1.89 \%$ of the total variation in the PCA analysis to be able to determine the components that are effective in the grouping. Biplot diagram was drawn based on the basic components of F1 and F2, it was observed that 50RCBH showed distinctive results in terms of bitterness, crumb brownness and cacao taste while $50 \mathrm{LCBH}$ separated with fibrousness, hardness (mouth \& hand), woody odor from other fat substituted cakes. 30LCBH cake differed from sweetness and adhesiveness properties. Panelists were also separated 40RCBH cakes based on oiliness, moistness and cell uniformity characteristics (Figure 3B). PCA and variance analysis of cakes showed similar results (Table 5). As it shown in PCA and variance analysis bitterness, oiliness, moistness, cell uniformity was higher in $\mathrm{RCBH}$ cakes than LCBH cakes and woody odor, fibrousness, hardness (mouth and hand) were less in RCBH cakes than LCBH cakes.

Table 4 Colour properties of cakes

\begin{tabular}{|c|c|c|c|c|c|c|c|}
\hline \multirow{2}{*}{ CS } & \multirow{2}{*}{$\begin{array}{c}\text { CHR } \\
(\%)\end{array}$} & \multicolumn{3}{|c|}{ Crust } & \multicolumn{3}{|c|}{ Crumb } \\
\hline & & $\mathrm{L}^{*}$ & $a^{*}$ & $\mathrm{~b}^{*}$ & $\mathrm{~L}^{*}$ & $a^{*}$ & $\mathrm{~b}^{*}$ \\
\hline Control & 0 & $47.10 \pm 1.40^{\mathrm{c} *}$ & $13.58 \pm 1.25^{\mathrm{d}}$ & $15.76 \pm 3.57^{\mathrm{c}}$ & $70.76 \pm 1.20^{\mathrm{d}^{*}}$ & $-0.85 \pm 0.35^{a}$ & $22.4 \pm 0.54^{\mathrm{d}}$ \\
\hline \multirow{3}{*}{$\mathrm{RCBH}$} & 20 & $42.94 \pm 3.75^{b}$ & $10.35 \pm 1.53^{\mathrm{c}}$ & $11.78 \pm 3.71^{b}$ & $38.77 \pm 3.20^{\mathrm{b}, \mathrm{c}}$ & $8.27 \pm 0.89^{c}$ & $9.20 \pm 2.80^{\mathrm{c}}$ \\
\hline & 30 & $40.29 \pm 3.62^{\mathrm{a}}$ & $9.36 \pm 0.93^{b}$ & $8.36 \pm 1.65^{\mathrm{a}}$ & $37.05 \pm 2.95^{\mathrm{a}, \mathrm{b}, \mathrm{c}}$ & $8.21 \pm 0.80^{\mathrm{c}}$ & $7.85 \pm 2.44^{\mathrm{b}, \mathrm{c}}$ \\
\hline & 40 & $40.16 \pm 3.48^{\mathrm{a}}$ & $9.15 \pm 0.93^{\mathrm{b}}$ & $8.42 \pm 1.20^{\mathrm{a}}$ & $35.64 \pm 3.41^{\mathrm{a}}$ & $7.97 \pm 0.61^{\mathrm{c}}$ & $6.72 \pm 1.69^{\mathrm{b}}$ \\
\hline \multirow{3}{*}{$\mathrm{LCBH}$} & 20 & $40.92 \pm 1.44^{\mathrm{a}, \mathrm{b}}$ & $8.58 \pm 0.56^{b}$ & $8.84 \pm 1.85^{\mathrm{a}}$ & $39.13 \pm 1.30^{\mathrm{c}}$ & $5.89 \pm 0.40^{\mathrm{b}}$ & $4.96 \pm 1.20^{\mathrm{a}}$ \\
\hline & 30 & $39.22 \pm 1.17^{\mathrm{a}}$ & $7.21 \pm 0.81^{\mathrm{a}}$ & $7.10 \pm 1.71^{\mathrm{a}}$ & $36.80 \pm 1.82^{\mathrm{a}, \mathrm{b}}$ & $5.90 \pm 0.45^{\mathrm{b}}$ & $4.20 \pm 1.18^{\mathrm{a}}$ \\
\hline & 40 & $39.12 \pm 1.07^{\mathrm{a}}$ & $6.94 \pm 0.72^{\mathrm{a}}$ & $7.11 \pm 2.37^{\mathrm{a}}$ & $34.79 \pm 1.55^{\mathrm{a}}$ & $5.71 \pm 0.56^{\mathrm{b}}$ & $3.37 \pm 1.31^{\mathrm{a}}$ \\
\hline
\end{tabular}

CS: Cake samples, CHR: Cocoa hull ratios, Means \pm standard deviation followed by different letters within a column for each cultivar are significantly different at $\mathrm{P}<0.05$

Table 5 Descriptive sensory analysis of RCBH and LCBH cakes

\begin{tabular}{l|cccccc}
\hline & $30 R C B H$ & $40 R C B H$ & $50 R C B H$ & $30 L C B H$ & $40 L C B H$ & $50 L C B H$ \\
\hline Crumb brownness & $3.75 \pm 0.21^{\mathrm{a}, b^{*}}$ & $4.75 \pm 0.07^{\mathrm{c}, \mathrm{d}}$ & $5.45 \pm 0.07^{\mathrm{d}}$ & $3.10 \pm 0.71^{\mathrm{a}}$ & $4.35 \pm 0.07^{\mathrm{b}, \mathrm{c}}$ & $5.05 \pm 0.07^{\mathrm{c}, \mathrm{d}}$ \\
Cell uniformity & $5.50 \pm 0.28^{\mathrm{c}}$ & $5.35 \pm 0.21^{\mathrm{b}, \mathrm{c}}$ & $4.90 \pm 0.28^{\mathrm{a}, \mathrm{b}}$ & $4.85 \pm 0.07^{\mathrm{a}, \mathrm{b}}$ & $5.05 \pm 0.07^{\mathrm{a}, \mathrm{b}, \mathrm{c}}$ & $4.80 \pm 0.14^{\mathrm{a}}$ \\
Hardness (hand) & $4.80 \pm 0.00^{\mathrm{a}}$ & $4.85 \pm 0.35^{\mathrm{a}}$ & $5.10 \pm 0.57^{\mathrm{a}}$ & $5.05 \pm 0.21^{\mathrm{a}}$ & $4.85 \pm 0.92^{\mathrm{a}}$ & $5.60 \pm 0.85^{\mathrm{a}}$ \\
Adhesiveness & $5.30 \pm 0.28^{\mathrm{d}}$ & $4.70 \pm 0.14^{\mathrm{a}, \mathrm{b}, \mathrm{c}}$ & $4.35 \pm 0.07^{\mathrm{a}}$ & $5.10 \pm 0.28^{\mathrm{c}, \mathrm{d}}$ & $4.85 \pm 0.07^{\mathrm{b}, \mathrm{c}}$ & $4.55 \pm 0.0^{\mathrm{a}, \mathrm{b}}$ \\
Hardness (mouth) & $4.00 \pm 0.14^{\mathrm{a}}$ & $4.60 \pm 0.00^{\mathrm{b}}$ & $4.70 \pm 0.00^{\mathrm{b}, \mathrm{c}}$ & $4.95 \pm 0.07^{\mathrm{c}, \mathrm{d}}$ & $5.00 \pm 0.14^{\mathrm{d}}$ & $5.40 \pm 0.14^{\mathrm{e}}$ \\
Oiliness & $4.70 \pm 0.14^{\mathrm{b}}$ & $4.65 \pm 0.07^{\mathrm{b}}$ & $4.10 \pm 0.14^{\mathrm{a}, \mathrm{b}}$ & $4.40 \pm 0.00^{\mathrm{a}, \mathrm{b}}$ & $3.95 \pm 0.64^{\mathrm{a}, \mathrm{b}}$ & $3.55 \pm 0.64^{\mathrm{a}}$ \\
Moistness & $4.65 \pm 0.21^{\mathrm{d}}$ & $4.35 \pm 0.07^{\mathrm{c}, \mathrm{d}}$ & $4.20 \pm 0.14^{\mathrm{b}, \mathrm{c}}$ & $3.90 \pm 0.14^{\mathrm{c}, \mathrm{d}}$ & $3.65 \pm 0.35^{\mathrm{a}, \mathrm{b}}$ & $3.25 \pm 0.21^{\mathrm{a}}$ \\
Fibrousness & $3.95 \pm 0.07^{\mathrm{a}}$ & $3.95 \pm 0.07^{\mathrm{a}}$ & $4.60 \pm 0.14^{\mathrm{b}}$ & $3.95 \pm 0.21^{\mathrm{a}}$ & $4.60 \pm 0.14^{\mathrm{b}}$ & $5.50 \pm 0.14^{\mathrm{c}}$ \\
Chocolate taste & $3.82 \pm 0.25^{\mathrm{a}}$ & $4.76 \pm 0.00^{\mathrm{b}, \mathrm{c}}$ & $5.26 \pm 0.08^{\mathrm{c}}$ & $3.95 \pm 0.68^{\mathrm{a}, \mathrm{b}}$ & $4.73 \pm 0.10^{\mathrm{b}, \mathrm{c}}$ & $4.89 \pm 0.34^{\mathrm{c}}$ \\
Bitterness & $3.50 \pm 0.71^{\mathrm{b}}$ & $3.90 \pm 0.14^{\mathrm{b}, \mathrm{c}}$ & $4.55 \pm 0.07^{\mathrm{d}}$ & $2.60 \pm 0.42^{\mathrm{a}}$ & $3.20 \pm 0.00^{\mathrm{a}, \mathrm{b}}$ & $4.30 \pm 0.00^{\mathrm{c}, \mathrm{d}}$ \\
Woody odour & $2.20 \pm 0.00^{\mathrm{a}, \mathrm{b}}$ & $2.10 \pm 0.00^{\mathrm{a}}$ & $2.50 \pm 0.14^{\mathrm{a}, \mathrm{b}}$ & $2.60 \pm 0.42^{\mathrm{a}, \mathrm{b}}$ & $2.55 \pm 0.07^{\mathrm{a}, \mathrm{b}}$ & $3.10 \pm 0.00^{\mathrm{c}}$ \\
Sweetness & $5.65 \pm 0.35^{\mathrm{a}}$ & $5.55 \pm 0.78^{\mathrm{a}}$ & $4.95 \pm 0.78^{\mathrm{a}}$ & $5.65 \pm 0.07^{\mathrm{a}}$ & $5.40 \pm 0.42^{\mathrm{a}}$ & $5.15 \pm 0.64^{\mathrm{a}}$ \\
\hline
\end{tabular}

Means \pm standard deviation followed by different letters within a column for each cultivar are significantly different at $\mathrm{P}<0.05$ 


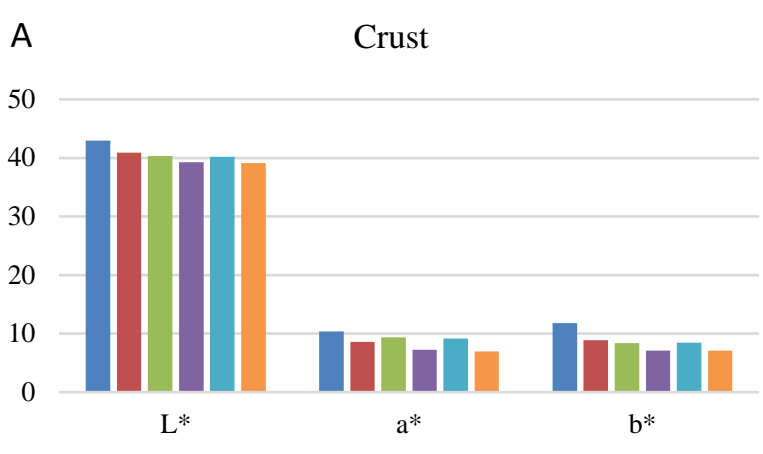

$\varpi 30 \mathrm{RCBH}=30 \mathrm{LCBH} \approx 40 \mathrm{RCBH} \approx 40 \mathrm{LCBH} \approx 50 \mathrm{RCBH} \backsim 50 \mathrm{LCBH}$
B

Crumb

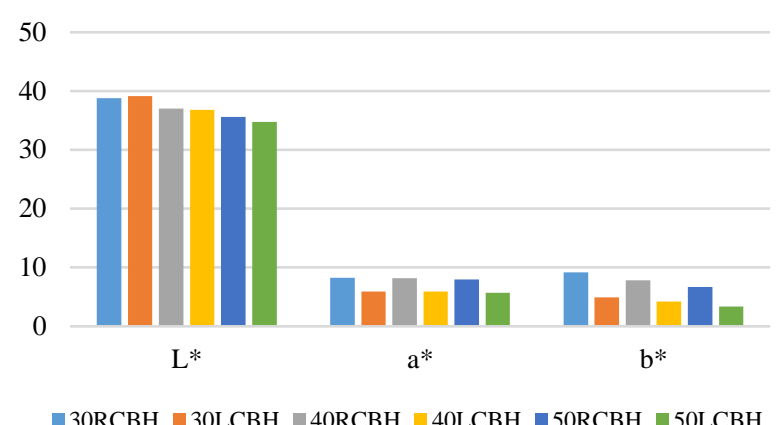

Figure1 Colour of cakes. A: Crust colour of cakes. B: Crumb colour of cakes

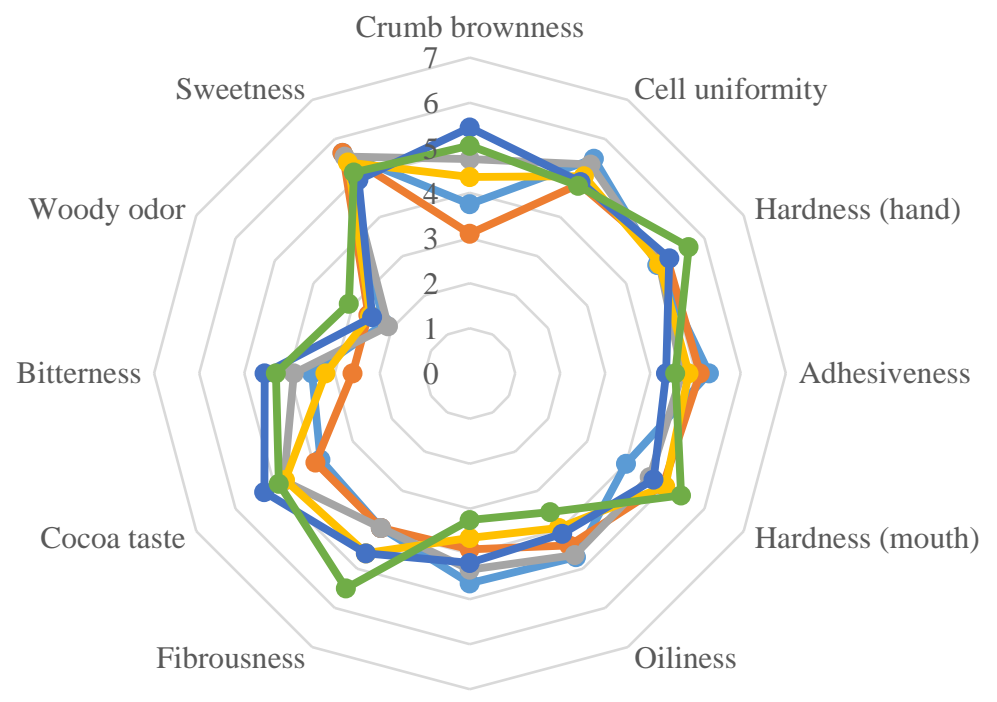

Moistness

$-30 \mathrm{RCBH}-30 \mathrm{LCBH}-40 \mathrm{RCBH}-40 \mathrm{LCBH} \longrightarrow 50 \mathrm{RCBH}-50 \mathrm{LCBH}$

Figure 2 Descriptive sensory analysis of cakes

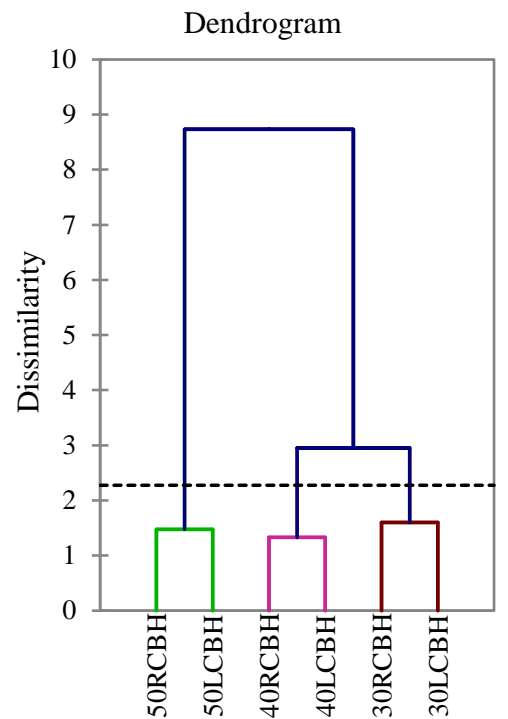

Biplot (axes F1 and F2: 88,83\%)

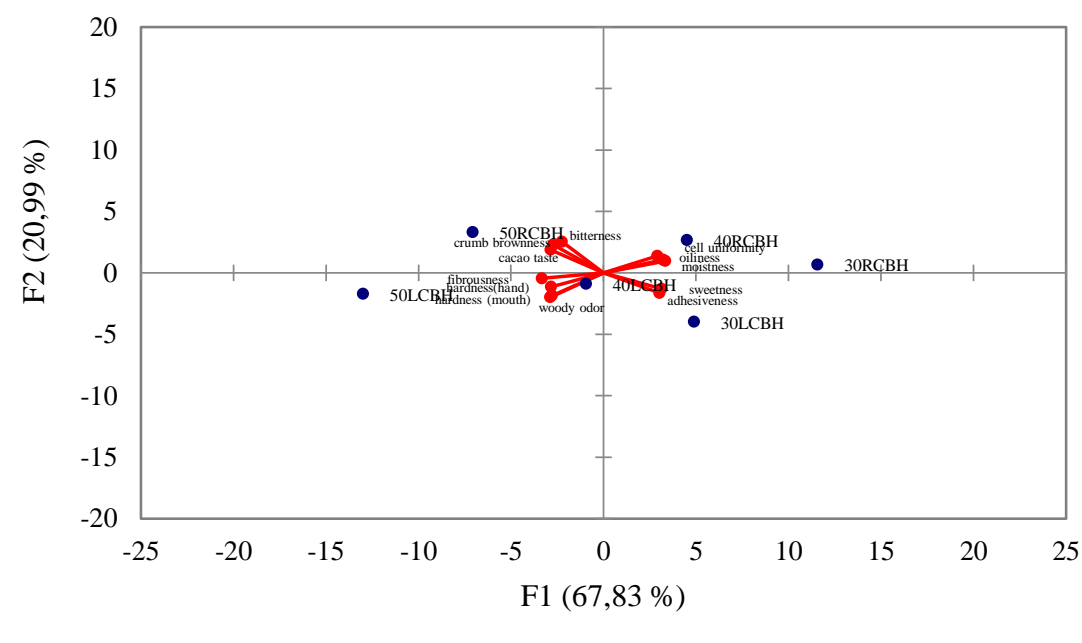

Figure 3 Principal component analysis of descriptive sensory analysis. A: Dendogram of cluster analysis B: Biplot diagram 
Martínez-Cervera et al. (2011) studied on soluble cocoa fiber in the ratio of $0 \%$ (control cake)-25\% - 50\% and $75 \%$ of fat for determining descriptive sensory analysis of low-fat chocolate muffins chocolate muffins. Full-fat was used in control chocolate muffin without any cocoa fiber. All muffin samples were prepared with the same quantity of sugar; soluble cocoa fiber didn't affect the perception of sweetness for all the samples. $75 \%$ fat replacement of muffin showed similar points with control muffin in terms of the chocolate color of samples. This result indicated that soluble cocoa fiber could be used as a color developer instead of cocoa powder. Sponginess and springiness of $25 \%$ fat substituted muffin were found similar scores to the control muffins. As cocoa fiber increased in muffins, cohesiveness, chewiness and swallowing properties increased with addition of cocoa fiber. Stickiness and bitter taste showed difference between fat substituted muffins and control muffin.

\section{Conclusions}

These findings show that ash, protein, total phenolic compounds, total antioxidant activity decreased with leaching process. Bioactive compounds, crude fiber contents of cakes increased with cocoa bean hull replacement as compared to control cake. Volume of fat substituted cakes showed no significant difference while baking loss of fat substituted cakes decreased in comparison with control cake. Regarding textural properties, hardness and chewiness of cakes with LCBH was found higher amounts than cakes with RCBH. As cell uniformity, moistness and oiliness of fat substituted cakes values increased, fibrousness, woody odor and hardness (mouth and hand) values of fat substituted cakes decreased based on the results of principal component and variance analysis.

From the whole results, raw cocoa bean hulls showed more advantages in chemical, physical and sensory properties of cakes. $50 \%$ of vegetable oil replaced with raw cocoa bean hulls for low calorie functional cake production could be recommended. In accordance with this study, raw cocoa bean hulls could be evaluated directly in the form of new functional products.

\section{Acknowledgements}

This research was funded by Ege University BAP (Scientific research project) with reference number, 16 MÜH 021. Cocoa bean hulls were supplied with ÜLKER Chocolate Inc.

\section{References}

AACC. 2000a. International. Approved methods of analysis. Method 44-40. 01. Moisture Modified Vacuum-Oven Method (10th ed.). St. Paul, MN: AACC International

AACC. 2000b. American Association of Cereal Chemists. Approved methods of analysis, Method 10-05. Rapeseed Displacement Method, 10th ed., St. Paul, MN, ABD.

AACC. 2000c. International. Approved methods of analysis. Method 74-09. 01-04. Bread Firmness by Universal Testing Machine. (10th Ed.). St. Paul, MN: AACC International
Altuğ T. 1987. Toz kakaoda tağşiş saptama metodları üzerine, PhD. Thesis (Supervisor: Dr. Meral Gönül), Ege University Engineering Faculty, Food Engineering Department, 76 p.

Altuğ T, Elmacı Y. 2005. Gidalarda Duyusal Değerlendirme, Meta Basım Matbaacılık Hizmetleri, 61-90 s.

AOAC. 2007. Association of Official Analytical Chemist. 2007. Official Methods of Analysis, 18th ed. MD, USA.

Arlorio M, Coisson JD, Restani P, Martelli A. 2001. Characterization of pectins and some secondary compounds from Theobroma cacao hulls. Journal Food Science, 66(5), 653-656.

Arlorio M, Coìsson JD, Travaglia F, Varsaldi F, Miglio G, Lombardi G, Martelli A. 2005. Antioxidant and biological activity of phenolic pigments from Theobroma cocoa hulls extracted with supercritical $\mathrm{CO} 2$, Food Research International 38, 1009 - 1014.

Balestra F, Cocci E, Pinnavaia G, Romani, S. 2011. Evaluation of antioxidant, rheological and sensorial properties of wheat flour dough and bread containing ginger powder, LWT Food Science and Technology, Volume 44, Issue 3, April 2011, Pages 700-705.

Beckett ST. 2008. The science of chocolate (Second). Cambridge: RSCPublishing.

Beckett ST. 2009. Industrial chocolate manufacture and use (4a ed.). Wiley-Blackwell.

Bruna C, Eichholz I, Rohn S, Kroh LW, Huyskens - Keil S. 2009. Bioactive compounds and antioxidant activity of cocoa hulls (Theobroma cocoa L.) from different origins, Journal of Applied Botany and Food Quality, 83: 9-13.

Chaplin MF. 2003. Fiber and water binding, Proceedings of the Nutrition Society, 62: 223-227.

Collar C, Rosell CM, Muguerza B, Moulay L. 2009. Breadmaking performance and keeping behavior of cocoasoluble fiber-enriched wheat breads. Food Science and Technology International, 15(1): 79-87.

Fernandes SS, Salas-Mellado MM. 2017. Addition of chia seed mucilage for reduction of fat content in bread and cakes. Food Chemistry, 227: 237-244.

Garcia-Serna E, Martinez-Saez N, Mesias M, Morales JF. Dolores del Castillo M. 2014. Use of Coffee Silverskin and Stevia to Improve the Formulation of Biscuits, Polish Journal of Food and Nutrition Sciences, Vol. 64, No. 4, pp. 243-251, http://journal.pan.olsztyn.pl

Heimler D, Vignolini P, Dini MG, Vincieri F, Romani A. 2005. Antiradical Activity and Polyphenol Composition of Local Brassicaceae Edible Varieties, Food Chemistry, 82: 15111517.

ICO. 2016. International Cocoa Organization Production of cocoa beans. ICCO Quarterly Bulletin of Cocoa Statistics, XLII.

Kongor JE, Hinneha M, Van de Walle D, Afoakwa OE, Boeckx, P, Dewettinck K. 2016. Factors influencing quality variation in cocoa (Theobroma cacao) bean flavour profile - A review, Food Research International, 82: 44-52.

Kopp GM, Pearson SM, Shah M. 2011. Process for milling cocoa shells, http://www.google.com/patents/US8067051 (Date accessed: 05.02.2017).

Lecumberri E, Mateos R, Izquierdo-Pulido M, Rupérez P, Goya, L, Bravo L. 2007. Dietary fiber composition, antioxidant capacity and physico-chemical properties of a fiber-rich product from cocoa (Theobroma cacao L.), Food Chemistry, 104: 948-954.

Martín-Cabrejas MA, Valiente C, Esteban RM, Mollá E. 1994. Cocoa hull: A potential source of dietary fiber. Journal of the Science of Food and Agriculture, 66: 307-311.

Martínez R, Torres P, Meneses MA, Figueroa JG, Pérez-Álvarez JA, Viuda-Martos M. 2012. Chemical, technological and in vitro antioxidant properties of cocoa (Theobroma cacao L.) co-products. Food Research International, 49: 39-45. 
Martínez-Cervera S, Salvador A, Muguerza B, Moulay L, Fiszman SM. 2011. Cocoa fiber and its application as a fat replacer in chocolate muffins, Food Science and Technology, 44: 729-736.

Okiyama DCG, Navarro SLB, Rodrigues CEC. 2017. Cocoa shell and its compounds: Applications in the food industry. Trends in Food Science \& Technology, 63: 103-112

Prasad M, Simmons P, Maher MJ. 2004. Release characteristics of organic fertilizers. Acta Horticulturae, 644: 163-170.

Rapisarda P, Tomaino A, Cascio R, Bonina F, De Pasquale F, Saija A. 1999. Antioxidant effectiveness as influenced by phenolic content of fresh orange juice. J. Agric. Food Chem., 47: 4718-4723.
Saija A, Trombetta D, Tomaino A, Lo Cascio R, Princi P, Uccella N, Bonina F, Castelli F. 1998. 'In vitro' evaluation of the antioxidant activity and bio membrane interaction of the plant phenols oleuropein and hydroxytyrosol, Int. J. Pharm., 166: 123-133.

Skerget M, Kotnik P, Hadolin M, Hras AR, Simonic M, Knez Z. 2005. Phenols, proanthocyanidins, flavones and flavonols in some plant materials and their antioxidant activities, Food Chemistry, 89: 191-198.

Yang J, Xiao A, Wang C. 2014. Novel development and characterization of dietary fiber from yellow soybean hulls, Food Chemistry, 161: 367-375. 